\title{
Komisyon'un COM (2020) 64 Final Raporu Işı̆̆ında Yapay Zekânın Hatalı İşleyişi İle İlgili Ürün Sorumluluğu Hukukuna İlişkin Düşünceler
}

\author{
Von RA Prof. Dr. Friedrich Graf von Westphalen, Köln ${ }^{* *}$
}

\author{
İpek B. Aldemir Toprak ${ }^{* * *}$ (D)
}

Avrupa Komisyonu'nun 19 Şubat 2020 tarihli "Yapay Zekâ, Nesnelerin İnterneti ve Robotiklerin Güvenlik ve Sorumluluk Bakımından Etkileri”"1 konulu raporunu yakın bir incelemeye tabi tutmak, en azından güncel durumlar için ilgi çekicidir. Bununla birlikte, söz konusu araçların kullanımında "güvenliğin" nasıl sağlanabileceği sorusu, yasal koşulların ağırlık noktasını oluşturmamalıdır. Zira bu yasal koşullar, yalnızca belirli (tamamlanmamış) bir bölüme kadar mevcuttur. Yapay zekânın - aynı zamanda nesnelerin interneti veya robotiğin - hatalı işleyişi ve bir zarara yol açtığı durumlar için öngörülen kavramsal hukukî esaslara dikkat etmek, tercihe şayan görünmektedir. Bununla birlikte, bu araçların kullanımında "güvenliğin” nasıl sağlanabileceğine dair yasal önkoşullara vurgu yapılmamalıdır, çünkü bunlar sadece belirli (eksik) bir dereceye kadar mevcuttur.

\section{A. Örüntünün Tanımlanması}

\section{Yapay Zekâ (KI), Nesnelerin Interneti (IoT) ve Robotik İçin}

Komisyon’un, aşağıdaki ifadesinde yer verdiği önemli özellikler, burada yapılacak değerlendirmeler ${ }^{2}$ için belirleyici niteliktedir:

"Yapay zekâ, nesnelerin interneti ve robotik birçok ortak özelliğe sahiptir. Bu özellikler, görevleri insanın hiç sevk ve idaresi veya denetimi olmadan ya da bunun çok azı ile yerine getirmek için bağlanabilirlik (Konnektivität), otonomi (Autonomie) ve veri bağımlılı̆̆ını (Datenabhängigkeit) birbiriyle ilişkilendirir. Ayrıca yapay zekâ destekli sistemler, kendi deneyimlerinden öğrenmek suretiyle performanslarını iyileştirebilirler. Bu sistemlerin karmaşıklığı (Komplexität), hem tedarik zincirinde (Lieferkette) yer alan ekonomik aktörlerin çeşitliliğinde hem de birlikte yeni teknolojik ekosistemler oluşturan bileşenlerin, parçaların, yazılımların, sistemlerin veya hizmetlerin çok sayıda

* $\quad$ Makale, "Produkthaftungsrechtliche Erwägungen beim Versagen Künstlicher Intelligenz (KI) unter Beachtung der Mitteilung der Kommission COM (2020) 64 final” başlı̆̆ ile VuR 2020, 248'de Almanca olarak yayınlanmış olup yazarın izni ile Türkçe’ye çevrilmiş ve yayınlanmıştır.

** Avukat.

*** Dr., Ankara Yıldırım Beyazıt Üniversitesi Hukuk Fakültesi Medenî Hukuk Anabilim Dalı

1 COM (2020) 64 Final Raporu.

2 Bu konuda ve Komisyon’un (COM 2020) 66 Beyaz Kağıt Raporu için bkz. Ebers, VuR 2020, 121; ayrıca Lachenmann, ZD-aktuell 2020, 07021; Yapay zekânın kullanımında ortaya çıkan geniş sorumluluk sorunları ile ilgili Komisyon'daki tartışmanın genel durumu hakkında en güncel bilgi için bkz. Seehafer/Kohler, EuZW 2020, 213 (217 f.). 
olmasında kendini gösterir. Buna ek olarak, söz konusu teknolojilerin piyasaya sürülmesinden sonra güncelleştirme ve iyileştirmeler için açıklık (Offenheit) bulunur. İlgili verilerin büyük miktarda olması, algoritmaların kullanımı ve yapay zekânın karar alma süreçlerinin şeffaf olmayışı (Opazität), yapay zekâ destekli bir ürünün davranışını öngörmeyi ve zararı ortaya çıkaran potansiyel nedenleri anlamayı zorlaştırmaktadır. Nihayetinde, bağlanabilirlik (Konnektivität) ve açıklık (Offenheit), yapay zekâ ve nesnelerin interneti ürünlerini siber tehditlere açık hale getirebilir”3.

Komisyon'un, burada bahsi geçen önemli terimlerin bazılarını, sonraki ifadelerinde daha geniş tanımlandığı vurgulanmalıdır ${ }^{4}$.

\section{Otonomi}

Komisyon, yapay zekânın soyut özelliklerinin içeriğini anlamak için gerekli olan otonomi kavramını şu şekilde tanımlamaktadır: “Otonomi, yapay zekânın temel özelliklerinden biridir. Yapay zekâdan kaynaklanan istenmeyen sonuçlar, kullanıcılara ve tehlikeye maruz kalan kişilere zarar verebilir"5.

Komisyon, bir yapay zekânın kendi kendine öğrenmesinin (“derin öğrenme”) genellikle geliştiricilerin kavramsal olarak önceden belirlediği ölçütlere göre gerçekleştiğini vurgulasa $\mathrm{da}^{6}$; sonuç itibariyle şu hususu göz önünde bulundurarakgörüşünü değiştirmeyi düşünmelidir: Yapay zekânın "kendi kendine öğrenme etkisi” nedeniyle "bir makine şartlara bağlı olarak üreticilerin başlangıçta amaçladığından ve bunun sonucunda kullanıcıların beklediğinden farklı kararlar alabilir”7. Bu konu, yapay zekânın başlangıçta yapılan tanımında detaylı olarak zaten ele alınmaktadır. Şöyle ki, bu tanımda, - özellikle "kendi kendine öğrenme etkisi” nedeniyle-, yapay zekânın görevleri "ya insanın sevk ve idaresi veya denetimi olmadan ya da yalnızca bunun çok azı" ile yerine getirmesinden bahsedilmektedir ${ }^{8}$. Komisyon, aynı zamanda “Avrupa Birliği’nin, mevcut ürün güvenlik düzenlemelerinde kendi kendine öğrenen yapay zekâ ürünleri ve sistemleri ile ilgili olarak insan denetimini açıkça ele almadığını” da belirtmektedir?.

3 COM (2020) 64 Final Raporu, 2 (Orijinal metindeki kalın yazı tipi ile yazılmış kısım).

4 Yapay zekânın hatalı davranması halinde ortaya çıkan farklı sorumluluk meseleleri ve uygun reform önerileri için bkz. Rott, (Bilirkişi Raporundan Alıntı), erișim adresi: https://www.vzbv.de/sites/default/files/downloads/ 2018/05/04/ gutachten_handlungsbedarf_im_haftungsrecht.pdf; Avrupa Tüketicinin Korunması Birliği (BEUC)'nin görüşü için bkz. Schmon, IWRZ 2018, $254 \mathrm{ff}$.

$5 \operatorname{COM}(2020) 64$ Final Raporu, 8.

6 COM (2020) 64 Final Raporu, Fn 34: “Yapay zekâ destekli ürünler, çevrelerini algılayarak ve önceden belirlenmiş talimatlara riayet etmeden otonom bir şekilde hareket edebilirler. Ancak bu ürünlerin davranışları, belirlenen amaç ve geliştiricilerinin ilgili diğer kavramsal kararları ile sinırlıdır."

7 COM (2020) 64 Final Raporu, 9.

8 COM (2020) 64 Final Raporu, 2.

9 COM (2020) 64 Final Raporu, 9. 


\section{B. Ürün Hatası Kavramına İlişkin Etki}

\section{Alman Ürün Sorumluluğu Kanunu'nun ilkeleri}

-Yapay zekâ, nesnelerin interneti veya robotiğin hatalı işleyişinden kaynaklanan sorumluluk risklerini - kişinin yaralanması, ölümü veya mala verilen zararı - BGB Art. 823 Abs. 1'den ortaya çıkarılan genel davranış yükümlülüğü kavramı ${ }^{10}$ gibi - yeterince kapsayan daha geniş uyumlaştırmalar yapılmalıdır. $\mathrm{Bu}$ uyumlaştırmalar olmadan ulusal haksız fiil hukuku ve dolayısıyla kusura bağlı sorumluluk sistemlerinin uygun olmayacağ ${ }_{1}$ açıktır. Bu sebeple, Komisyon'un - yapay zekâ, nesnelerin interneti ve robotiğin tanımına ilişkin ele alınması gereken diğer düşünceleri de dâhil - ulusal haksız fiil hukukunda değişiklik yapılmasının ne ölçüde uygun ve gerekli olduğu sorusu cevaplandırılmalıdır. Komisyon tarafından ortaya atılan bu sorunun cevaplandırılması için ${ }^{11}$ 1985/374 sayılı Üreticinin Sorumluluğuna İlişkin Avrupa Konseyi Direktifi'nin ${ }^{12}$ hükümlerine başvurulması gerekir ${ }^{13}$. Zira, bu Direktif'te hatalı ürünlerden doğan sorumluluk ile tüketicinin haklarının korunması için yasal bir tehlike sorumluluğu yani: üreticinin, kısmî üreticinin ve son olarak da nihaî dağıtıcının kusursuz sorumluluğu öngörülmektedir. Dolayısıyla, yapay zekâ, nesnelerin interneti ve robotiğin hatalı bir davranışı için daha geniş mülahazaların temeli olarak sadece bu unsurdan yola çıkılması güvenilirdir ${ }^{14}$. Bu çıkış noktası, aşağıda yer alan diğer düşüncelere yol açmaktadır:

\section{I. Ürün Olarak Yazılım}

Almanya’da Ürün Sorumluluğu Kanunu’nun 2. maddesine ${ }^{15}$ ilişkin yorumlar, sürekli olarak “yazılımın” da bu düzenleme anlamında ürün olarak ${ }^{16}$ nitelendirilmesi gerektiğini ifade etmektedir ${ }^{17}$. Fakat Komisyon, haklı olarak yazılımın - cismanî olmayan - ürün veya hizmet olarak sınıflandırılmasının göz önünde bulundurulması gerektiği görüşündedir ${ }^{18}$. Komisyon’a göre: "Cismanî bir ürünün sevk ve idaresini kontrol etmek için oluşturulan yazılım, her ne kadar bu ürünün parçası veya bütünleyici parçası olarak kabul edilebilecekse de; bağımsız yazılımın kendine özgü bazı formlarını

10 Bu konuda ayrica bkz. Foerste, in: Foerste/Graf von Westphalen, Produkthaftungs-Handbuch, 3. Aufl. 2012 , \$24 Rn. 3 ff.

11 Bu Direktif'in yorumundan ortaya çıkan yapay zekânın hatalı davranışından doğan sorumluluğa ilişkin sorular için bkz. Seehafer/Kohler, EuZW 2020, 213 ff.; de Meuss, EuCML 2019, 149 (153); Riehm/Meier, EuCML 2019,161 (164 ff..); otonom sürüş sorunlarına dair güncel bilgi için bkz. Teichmann/Falker, CCZ 2020, 89 vd.; temel hakların, özellikle de insan onurunun güvence altına alınmasılla ilgili olağandışı zor sorular hakkında kapsamlı bilgi için bkz. Geminn, DÖV 2020, 172 ff.; AB Dijital Temel Haklar Şartı'na duyulan ihtiyaç için bkz. Graf von Westphalen, BB 2018, 899 ff.

12 ABl. 1985, L210/29, 07.08.1985.

13 Kapsamlı antoloji için bkz. Lohsse/Schulze/Staudenmayer, Liability for Artificial Intelligence and the Internet of Things, 2019, Eserin muhtelif yerlerinde.

14 COM (2020) 64 Final Raporu, 14.

15 "Bu kanun anlamında ürün, başka bir taşınır veya taşınmaz eşyanın parçası olsa bile, taşınır bir eşya ve elektriktir."

16 Rott, Bilirkişi Raporu (Fn 4), 15 ff.

17 MünchKommBGB/Wagner, 7. Aufl. 2017, ProdHaftG, $\$ 2$ Rn. 20; BeckOGK/Rebin, Stand: 01.03.2020, $\$ 2$ ProdHaftG Rn. 54; Graf von Westphalen, in: Foerste/Graf von Westphalen (Fn.10), $\$ 47$ Rn. 40 ff.; standart yazilım ile ilgili olarak bkz. Taschner/Frietsch, Produkthaftungsgesetz und EG-Produkthaftungs-Richtlinie, 2. Aufl. 1990, Art. 6 Rn. 28 ; güncel bilgi için bkz. Wagner, AcP 217 (2017), 708 (717 f.). 
sınıflandırmak çok zor olabilir"19. Ürünler ve hizmetler, giderek daha fazla birbirine bağlanmakta ve etkileşime girmektedir. Bundan dolayı, Komisyon haklı olarak karmaşıklık yönünü vurgulamaktadır. Zira yapay zekâ uygulamaları, sıklıkla "birçok farklı ağa bağlı cihazların ve hizmetlerin etkileşime girdiği karmaşık nesnelerin interneti çevrelerine entegre edilir”20.

\section{Yapay Zekânın Karmaşıklığı Yönü}

Daha da gelişecek karmaşıklık düşüncesi, zarar görenin belirli bir ürün hatası dolayısıyla ispat etmekle yükümlü olduğu ürün sorumluluğu hukukuna ilişkin nedensellik sorunlarını açıç̧a etkiler. Burada Alman Ürün Sorumluluğu Kanunu’nun 2. maddesinde yer alan "ürün” tanımı dikkate alındığında, Komisyon'un - yapay zekâ, nesnelerin interneti ve robotiklerin sorumluluğu ile ilgili olarak - her durumda yazılıma özgü hizmetleri ${ }^{21}$ ve dolayısıyla neden olunan hatalardan sorumluluğu kapsayan yeni bir tanım denemekten kaçınmayacağına dikkat çekilmelidir.

Bununla birlikte, daha yakından bakıldı̆̆ında Komisyon'un derinlemesine incelenmesi gereken ifadesinin biraz şifreli olduğu anlaşılmaktadır. Şöyle ki, Komisyon’a göre: “Ürün Sorumluluğu Direktifi’nde "ürün” kavramı geniş ele alınmaktadır. Buna rağmen, yeni teknolojilerin karmaşıklığını daha iyi hesaba katmak ve hatalı ürünlerin yazılım veya diğer dijital özellikler nedeniyle yol açtıkları zararların daima tazminini sağlamak için bu kavramın uygulama alanı, daha da açıklığa kavuşturulabilir"22.

Öyleyse tazminat sorumluluğunun tespit edildiği merkezî kavram, “ürün” değil, bilakis öncelikle "hatalı" üründür. Böylece Komisyon'un söz konusu ifadeleri-(kendi kendine öğrenen) bir yapay zekânın hatalı davranması hali de dâhil - tüm hukukî sorumluluk meselelerinin “ürünün” bir hatasının varlığına bağlı olduğu temel düşüncesini belirleyici bir şekilde doğrulamaktadır. Bununla birlikte, görüleceği gibi her şey otonom çalışan bir yapay zekâda böyle bir hatayı tespit etmeye bağlıdır ${ }^{23}$. Bu, kilit noktayı oluşturmaktadır ${ }^{24}$.

\section{II. Ürün Hatası - Yapay Zekânın Otonom Davranışları}

\section{Alman Ürün Sorumluluğu Kanunu'nun 3. Maddesine Göre Çıkış Noktası}

Bu noktada zarlar atılıyor ${ }^{25}$. Alman Ürün Sorumluluğu Kanunu'nun 3. maddesine göre, ürün hatasının (şu ana kadar ki) tanımı, zarara yol açan bir ürün hatasının - ideal - kullanıcının haklı

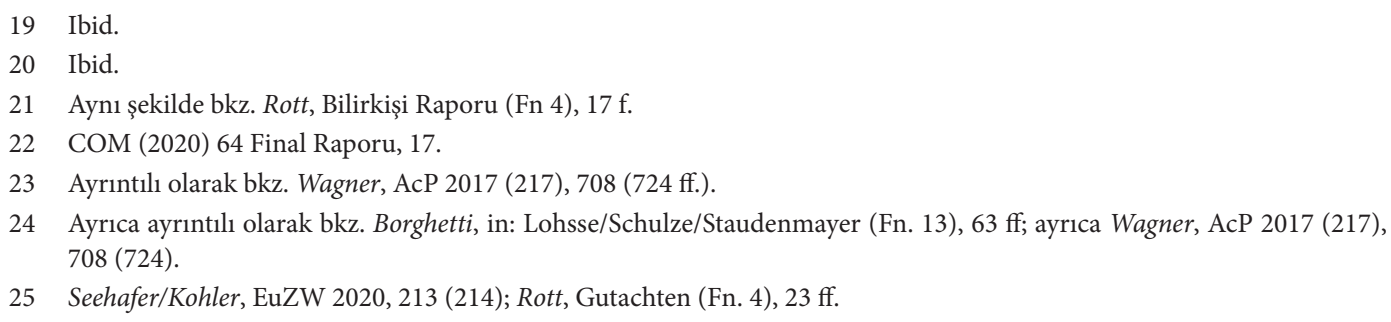


güvenlik beklentilerine aykırı olduğuna dayanmaktadır ${ }^{26}$. Bu açıdan bakıldığında "hata" kavramı salt sebebe bağlı sorumluluktan kaçınmak için ek bir sorumluluk şartı ${ }^{27}$ olarak anlaşılmalıdır ${ }^{28}$. Şöyle ki, sorumluluğu oluşturan bu unsurdan vazgeçilirse, ispat sorunu ağırlaştırılmış sebebe bağlı sorumluluk kapsamında belirleyici hâle gelecektir: Zarar gören daha sonra "sadece", ürünün amaçlanana uygun ${ }^{29}$ veya öngörülebilir; ancak belirlenenin aksine kullanımı sırasında ${ }^{30}$ zarara uğradığını kanıtlamak zorunda kalacaktır. Bu ispat edildiği taktirde, söz konusu "ürünün” hatalı olduğu ve kullanıcı için bütün koşullar dikkate alındığında ${ }^{31}$ - sosyal uygunluk bakımından - beklenebilecek güvenliğin sağlanmadığı da kanıtlanmış olur ( $\$ 3$ Abs. 1 ProdHaftG).

\section{Komisyon'un Imaları: Yapay Zekânın Kullanılması Hâlinde Sebebe Bağı Sorumluluk}

Komisyon özellikle yapay zekânın kullanılması hâlinde sebebe bağlı sorumluluğu, onun hatalı davranışından doğan sorumluluğun özelliklerini dikkate alarak daha açık bir dille şöyle anlatmaktadır: "Karmaşık bir ekosistemde farklı dijital bileşenlerin kombinasyonuyla" şekillenen ve "katılımcı aktörlerin çeşitliliği” ile karakterize olan yapay zekânın hatalı davranışı üstesinden gelinmesi gereken sıkıntıdır ${ }^{32}$. Bu sebeple, Komisyon, - bir ürünün birleştirildiği veya bir hizmet olarak piyasaya sürüldügü yazılımlar da dâhil olmak üzere - “ürün” terimini açıklığa kavuşturmaya çalışmaktadır. Tekrarlamak gerekirse, “yazılım veya diğer dijital özelliklerden kaynaklanan hatalı ürünlerin neden olduğu zararların daima tazmin edilmesini sağlamak” hukuk politikasının amacıdır ${ }^{33}$.

\section{3. Özel Problem: Yapay Zekânın Sonraki Değişiklikleri}

a) Mevcut Hukukî Durum Yapay zekânın hatalı davranışları ve bunun sonucunda ortaya çıkan zarar için sebebe bağlı sorumluluk düşüncesi takip edilirse, Komisyon’un başlangıçta yapay zekâyı karakterize etmek için kullandığı "açıklık” kavramının devreye sokulması gerekir. Komisyon raporunda, "bu teknolojilerin piyasaya sürülmesinden sonra, güncellemeler ve iyileştirmeler için açıklık olduğunu” ifade etmektedir ${ }^{34}$. Alman Ürün Sorumluluğu Kanunu'nun 1. maddesinin şu ana kadarki anlayışından hareket ederek üreticinin, ürettiği ve aynı zamanda piyasaya sürdügü bir ürünün objektif olarak gerekli ve kendisinden beklenen güvenlik kurallarına riayet edip etmediği ve uygun önlemleri alıp almadığı sorusu değerlendirilirken, yalnızca piyasaya sürme ânı esas alınır. Piyasaya sürülme ânında, ürün hatasının mevcut olması gerekir ${ }^{35}$. Bu ise zarar gören tarafından ispat

26 BeckOGK/Goehl, Stand: 01.06.2019, § 3 ProdHaftG Rn. 17; Graf von Westphalen, in: Foerste/Graf von Westphalen (Fn. 10), $\$ 49 \mathrm{Rn} .10 \mathrm{ff}$.

27 MünchKommBGB/Wagner (Fn. 17), $\$ 3$ ProdHaftG Rn. 1.

28 Graf von Westphalen, in: Foerste/Graf von Westphalen (Fn. 10), 448 Rn. 1.

29 BGH NJW 1988, 2611 - Patlayan limonata şişesi kararı.

30 MünchKommBGB/Wagner (Fn. 17), § 3 ProdHaftG Rn. 23.

31 BeckOGK/Goehl (Fn. 26), \$3 ProdHaftG Rn. 33 ff.

32 COM (2020) 64 Final Raporu, 17.

33 Ibid.

34 COM (2020) 64 Final Raporu, 2 (Orijinal metindeki kalın yazı tipi ile yazılmıs kısım).

35 Özellikle ayrıntılı olarak bkz. Graf von Westphalen, in: Foerste/Graf von Westphalen (Fn. 10), $\$ 46$ Rn. 33 ff. 
edilmelidir ${ }^{36}$. Dolayısıyla, ürün kullanıcısının (haklı) güvenlik beklentilerinin garantörü, geliştirme, tasarım $^{37}$, üretim ve talimat sırasında borçlanılan güvenlik önlemlerinin uyumlu hale getirilmesi gereken bilim ve teknolojinin o anki durumudur ( $\$ 1$ Abs. 2 Nr. 5 ProdHaftG) $)^{38}$.

BGB Art. 823 Abs. 1'de düzenlenmiş olan haksı fiil hukuku iki özellik ile karakterize edilir: Bunlardan ilki, Alman Federal Mahkemesi'nin kararına göre, - zarar gören rolüyle de - bir tüketicinin mutlak güvenlik bekleyemeyeceğidir ${ }^{39}$. Alman Federal Mahkemesi vermiş olduğu karar ile bir ürünün üreticisinin yerine getirmesi gereken güvenlik gereklerini, orantılılık esası ile uyarlayarak şu ilkeyi doğrulamaktadır: Ürün ne kadar tehlikeli olursa, güvenlik gerekleri de hem borçlanılan genel davranış yükümlülüklerinin objektif bakımdan yerine getirilmesi için hem de beklenebilirlik unsuru açısından o kadar yüksek olur ${ }^{40}$. - İkinci olarak - üretici, bir ürünün piyasaya sürülmesinden sonra - beklenmeyen ve öngörülmeyen bir hatanın bulunduğu bilgisini elde ederse, BGB $\$ 823$ Abs. 1 kapsamında, tehlikeyi önleme yükümlülüğünü - ürün gözlem yükümlülügüun̈̈ ${ }^{41}$ - bir uyar1 ${ }^{42}$ veya ürünün geri çağrılması şeklinde yerine getirir. Ürünün geri çağrılması, özellikle ürün güvenliği hukuku kapsamında - aynı zamanda resmî bir düzenlemenin temeli ( $\$ 26$ Abs. 2 Nr. 7 ProdSG $)^{43}$ olarak kabul edilir ${ }^{44}$.

b) Komisyon’un Değerlendirmeleri Alman Ürün Sorumluluğu Kanunu hükümleri, herhangi bir ürün gözlemleme yükümlülüğ $\ddot{u}^{45}$ öngörmemektedir ${ }^{46}$. Bu husus dikkate alındığında, Komisyon'un haklı olarak kullanmaya başladığı yapay zekâ sistemlerinin "açıklığı”, bir ürünü "piyasaya sürme” kavramının zararın ortaya çıkması halinde artık sorumluluğu belirleyici bağlama noktası olarak ele alınmamasına yol açmaktadır. Komisyon bu hususu şu şekilde ifade etmektedir: "Ürünlerin değișebileceği ve değiştirilebileceğini göz önünde bulundurmak için, Ürün Sorumluluğu Direktifi'nde kullanılmakta olan 'piyasaya sürme’ terimi, Avrupa Birliği’nin ürün güvenliği kapsamında yer alan

36 İspat yükü özellikle de Direktif'e göre bir sorumluluk kapsamında yer alan ispat derecesi ile ilgili çeşitli sorunlar için bkz. Rott, Gutachten (Fn. 4), 26 ff.

$37 \S 1$ f. 2/5 ProdHaftG yalnızca bu hata kategorisinde uygulanır. Zira bu hüküm, sadece gelişim riskleri ile ilgilidir. Bu yüzden bir fabrikasyon hatasının varlığı halinde bu hükme başvurulmaz. Bkz BGH NJW 1995, 2162 (2163) - Geri dönüşümlü cam şişe kararı.

38 BeckOGK/Seibl, Stand: 01.02.2020, \$ 1 ProdHaftG Rn. 121; Wagner, AcP 217 (2017), 708 (724 ff.); Alman Federal Mahkemesi kararı için bkz. BGH NJW 2009, 2952 (2955) - Hava yastığı kararı.

39 Ayrintı olarak bkz. Wagner, AcP 217 (2017), 708 (728 f.).

40 BGH NJW 2009, 1669, Rn. 8 ff. - Kiraz vadisi kararı; ürün sorumluluğu dişında, fakat $\$ 823$ Abs. 1 BGB kapsamında ayrıca bkz. BGH NJW 2013, 48, Rn. 7 f. - Dal kırılması kararı.

41 Kapsamlı bilgi için bkz. Foerste, in: Foerste/Graf von Westphalen (Fn. 10), $\$ 24$ Rn. 372 ff.

42 Temel karar BGH NJW 2009, 1080 - Bakım yatakları karar1; ayrıca Klindt, BB 2009, 792; Molitoris, NJW 2009, 1049; Avrupa Adalet Divanı Kararı için de bkz. VersR 2015, 900 - Boston bilimsel kararı; bunu takiben BGH VersR 2015, 1038; ayrintılı olarak bkz. Koch, VersR 2015, $1467 \mathrm{ff}$.

43 Bu konuda bkz. Schucht, in: Klindt, Produktsicherheitsgesetz, 2. Aufl. 2015, § 26 ProdSG Rn. 155 ff.

44 Ayrıca bkz. MünchKommBGB/Wagner (Fn. 17), \$823 Rn. $841 \mathrm{ff}$.

45 Pasif ve aktif yükümlülük arasındaki fark için bkz. Kullmann, NZV 2002, 1 (6); Foerste, in: Foerste/Graf von Westphalen (Fn. 10), §24 Rn. 376 .

46 Graf von Westphalen, in: Foerste/Graf von Westphalen (Fn. 10), $\$ 46$ Rn. 69; ayrıca: BGH BB 1970, 1414 - Bremsen; ayrıca kapsamlı olarak bkz. BGH NJW 2009, 1080 - Bakım yatakları kararı. 
ilgili değişikliklerle sıkı bir uyum içinde revize edilebilir. Ayrıca bu, bir üründeki değişikliklerden kimin sorumlu olduğunu açıklığa kavuşturmaya da katkıda bulunabilir”"47.

Komisyon bu bakış açısını, piyasaya sürülecek bir yapay zekânın gerekli risk değerlendirmesi bağlamında benimser ve üreticinin ürünü gözlemleme yükümlülüğü olduğunu esas alır. Komisyon’a göre: "Ürünün piyasaya sürülmesinden önce yapılan risk değerlendirmesine ek olarak, kullanım süresi boyunca esaslı değişikliğe uğrayan ürünlere yeni bir risk değerlendirme yöntemi uygulanabilir. Üreticinin başlangıçtaki risk değerlendirmesinde öngöremediği bir değişikliğin ürünün işleyişinde ortaya çıkması esaslı değişikliğe örnek teşkil eder. Bu risk değerlendirmesi, otonom davranışın ürünün tüm kullanım süresi boyunca güvenlik üzerindeki etkilerine odaklanmalıdır. Söz konusu değerlendirme, ilgili ekonomik aktör tarafından yerine getirilmelidir. Ayrıca, Avrupa Birliği'nin ilgili hukukî düzenlemeleri, üreticilere kullanıcılar için ürün kullanım talimatları ve uyarılar sunmalarına ilişkin daha sıkı şartlar getirebilir" ${ }^{38}$.

Ancak bu ifadenin önemli noktası, - kendi kendine öğrenen - bir yapay zekânın en ileri görüşlü güvenlik ve risk testlerinin bile, "tüm kullanım süresi boyunca” yapay zekânın davranışının otonom olması ilkesinden kaynaklanan değişiklikleri hesaba katamamasıdır.

\section{C. Özel Yönler: Yapay Zekânın Otonom Olması ve Kendi Kendine Öğrenme Etkisi}

\section{Konu}

Bir ürün kullanıcısı, esasen Alman Federal Mahkemesi’nin içtihadı anlamında piyasaya sürülen bir ürünü amacına uygun kullandığı taktirde kişi varlığı haklarının zarar görmeyeceğine ilişkin bir beklentiye sahiptir veya böyle bir beklentiye sahip olabilir. Yapay zekâ, nesnelerin interneti veya robotiğin kullanımında da - doğal olarak - bundan yola çıkılması gerekir ${ }^{49}$. Komisyon da "piyasaya sürülen bütün ürünlerin, kullanım süresi boyunca ve makul olarak beklenebilecek kullanım için güvenli olduğu" çıkış noktasını kabul etmektedir ${ }^{50}$.

$\mathrm{Bu}$ iyi gerekçelendirilmiş bakış açısı kendi kendine öğrenen yapay zekânın etkilerine dair bir ikileme yol açar. Zira yapay zekânın kendi kendine öğrenme etkisi, özelliklerini değiştirmesini ifade eder. Komisyon raporunda şu ifadelere yer vermektedir: "Otonomi, - güvenlik özellikleri de dâhil - ürünün özelliklerini önemli ölçüde değiştirebildiği için bir ürünün güvenliğini olumsuz etkileyebilir"51.

$\mathrm{Bu}$ düşünce, yapay zekânın otonom yapısı ve kendi kendine öğrenme etkisi sebebiyle oluşan kullanıcının güvenliği için zararlı değiş̧iklikleri, üreticinin bilim ve tekniğin durumuna göre ( $\$ 1$ Abs.

47 COM (2020) 64 Final Raporu, 19.

48 COM (2020) 64 Final Raporu, 9.

49 BGH NJW 1990, 906 - At nakil vagonu kararı.

50 COM (2020) 64 Final Raporu, 19.

51 COM (2020) 64 Final Raporu, 19. 
2 Nr. 5 ProdHaftG) engelleyip engelleyemeyeceğine ${ }^{52}$ ve sonuç olarak öngörüp öngöremeyeceğine ${ }^{53}$ kaçınılmaz bir şekilde yol açar. Burada gelecekteki sorumluluk kuralının önemli bir noktası yer almaktadır. Zech'in temel düşüncelerine ${ }^{54}$ riayet edilirse, kendi kendine öğrenen yapay zekânın belirli bir hata marjının bulunduğu ve zarara yol açmasının,-"doğasında yer alan bir davranış" olduğu - hesaba katılmalıdır ${ }^{55}$. Bu durum, yapay zekânın temelinde yatan (matematiksel) aksiyomun bir sonucudur. Söz konusu olgu, - ön değerlendirmede - zarara neden olan yapay zekâ davranışının öngörülebilirliğinin sınırlı olmasına yol açar. Ancak - nihaî değerlendirmede - bu durum, zararın gerçek sebebinin sınırlandırılmış bir şekilde "aydınlatılmasını" ve "açıklanmasını" sağlar ${ }^{56}$.

Zarar görenin ispat yükünü ağırlaştıran problemler ayrıca ele alınacaktır. Bununla birlikte, öncelikle hukuk politikası açısından çözülmesi gereken temel bir soru ön plâna çıkmaktadır. Bu soru kendi kendine öğrenen ancak zarara yol açan bir yapay zekânın artık risklerinin, zarar görene mi yüklenmek isteneceği; yoksa zarara neden olan hatalı davranışı için sebebe bağlı sorumluluk kurmaya yönelik çözüm yaklaşımının mı tercih edileceğidir. İkinci yol benimsenecek olursa, üreticinin mi yoksa yapay zekâ işleteninin mi sorumlu tutulduğunun yeniden açlklanması gerekir. İşletenin sorumlu tutulması, - motorlu araç işletenin ağırlaştırılmış sorumluluğunda olduğu gibi - üreticinin sorumluluğunu hafifletir ${ }^{57}$. Yapay zekânın ortaya çıkardığı zarar verici durumları - motorlu aracın malî mesuliyet sigortasına benzer şekilde - zorunlu sigorta ile "herkesin omzuna yüklemek" alternatif bir yoldur ${ }^{58}$. Bu husus da ele alınacaktır.

\section{Yapay Zekânın Kendi Kendine Öğrenme Etkisinin Olası Sonuçları}

Komisyon'un ifadesi benimsenirse, - otonom olması ve "kendi kendine (derin) öğrenmesi" nedeniyle - bir yapay zekâ, "üreticilerin başlangıçta amaçladığı ve bunun neticesinde kullanıcıların beklediğinden farklı" kararlar alabilir ${ }^{59}$. Fakat o zaman da "insan kontrolüne" ilişkin bir soru ortaya çıar ve bununla da Komisyon’un da ifade ettiği gibi, insanın "seçtiği hedeflere ulaşmak için kararlar almayı, yapay zekâ ürünlerine ve sistemlerine devretmesine"60 hukuk düzeninin (temel hakların vazgeçilemez koruması nedeniyle de) cevaz verip vermeyeceği sorusu daha da genişler. Bu durum, belirtildiği üzere - yapay zekânın öngörülemeyen hatalı davranışları nedeniyle, doğası gereği kusurlu olduğunu ifade eder. Komisyon’a göre: “Otonom hareket eden yapay zekâ uygulamaları, önceden

52 Ayrıntılı bilgi için bkz. Avrupa Adalet Divanı v. 29.05.1997, Rs. C-300/95 - Kommission/Vereinigtes Königreich, ECLI:EU:C:1997:255, BeckRS 2004, 76148 -Art. 7 lit. e ilişkin ulusal mahkemenin üstesinden gelmesi gereken yorum zorlukları; ayrıca gelişim risklerinden doğan sorumluluğun istisnasına ilişkin olarak bkz. Rott, Gutachten (Fn. 4), 35 f.

COM (2020) 64 Final Raporu, 19.

Zech, Liability for Autonomous Systems: Tackling Specific Risks of Modern IT, in: Lohsse/Schulze/ Staudenmayer (Fn. 13), 187 (192 f.).

Zech, ZfPW 2019, 198 (205).

Ibid.

Ayrıntı ve rücu aracı olarak ürün sorumluluğu” düşüncesi (otonom sürüş) için bkz. Wagner, AcP 217 (2017), 708 (759 f.).

Bunun için ayrıca bkz. Borges, New Liability Concepts: the Potential of Insurance and Compensation Funds, in: Lohsse/ Schulze/Staudenmayer (Fn. 13), $145 \mathrm{ff}$.

COM (2020) 64 Final Raporu, 9.

Ibid. 
herhangi bir adım tespit edilmeksizin bir görev icra ederler ve insanlar tarafından çok az miktarda idare edilip denetlenebilir veya sonuç itibariyle hiç sevk ve idare edilmez ya da denetlenmezler" ${ }^{\text {. }}$. Komisyon'un bu ifadesi, insanoğlunun sorumluluk hukuku bakımından mesul tutulmaktan ne kadar çok kurtulması gerektiğini açıklığa kavuşturmaktadır.

Ancak burada sorumluluk hukuku bakımından, - şahsî kusur kavramından bağımsız olarak yapay zekânın, insan tarafından artık sevk ve idare edilmeyen veya denetlenmeyen davranışı ve bu şekilde neden olunan zarar için karar verilmelidir. Zarar görenin, yapay zekâyı amacına uygun veya öngörülebilir biçimde belirlenenin aksine kullanması halinde uğradığı zarar ile yalnız bırakılmaması, sadece hukuk politikasına ilişkin temel bir talep olarak kabul edilebilir ${ }^{62}$.

\section{Yapay Zekânın Veri Miktarının Olası Sonuçları}

Komisyon'un düzenleyici açıklamaları gereği yapay zekânın hatalı davranışından doğan ağırlaştırılmış sorumlulukta - ve bunun sonucunda kullanıcının maruz kaldığı zararda - dikkate alınması gereken şartları açıklığa kavuşturmak için başka bir husus daha hesaba katılmalıdır. Komisyon’a göre yapay zekâ tarafından desteklenen tüm ürün ve sistemlerin bir özelliği de "verilere bağımlılıktır"63. Üretim sürecinin parçası olarak işlenen ve "derin öğrenmeye” uygun olarak sürekli işlenecek büyük veri miktarları karşısında Komisyon, "yapay zekâ destekli sistemlerin ve ürünlerin, üreticinin amaçladığı kararları almasını sağlamak için verilerin doğruluğunun ve konuya olan ilgisinin büyük önem taşıdığını” tespit etmektedir ${ }^{64}$.

Komisyon bu noktada yapay zekânın veri miktarından da kaynaklanan olası hatalı davranma riskini doğrudan hedef almamaktadır. Fakat Avrupa Birliği’nin güvenlik düzenlemelerinde mevcut olan eksikliği, “Avrupa Birliği’nin ürün güvenliği düzenlemelerinde hatalı verilerden kaynaklanan güvenlik riskleri açıkça ele alınmamaktadır." diyerek vurgulamaktadır ${ }^{65}$.

Ancak burada, şu temel gerçek dikkate alınmalıdır: Avrupa Birliği hukukundaki belgelerin kabulü tecrübelere göre en az beş yıllık bir süre gerektirir. Bir yapay zekânın, aynı zamanda nesnelerin interneti ve robotiklerin gelişim ve yenilenme döngüsü ise kural olarak bir yıldan çok daha az bir zaman almaktadır. Bu durum tıpkı bir kirpi ve tavşan arasındaki yarışa benzer. Dolayısıyla, Komisyon’un ileri sürdüğü “Avrupa Birliği’nin ürün güvenliği düzenlemelerinin, tasarı aşamasında hatalı verilerden kaynaklanan güvenlik risklerini dikkate almak için özel gereksinimleri ve yapay zekâ ürün ve sistemlerinin bütün kullanım süresi boyunca, veri kalitesinin korunması için mekanizmaları içermesinin gerekip gerekmediği” sorusu ${ }^{66}$, neredeyse 1 ssız ormanda çaresizce bağırmak gibi okunabilir.

61 COM (2020) 64 Final Raporu, 18.

62 BGH VersR 1972, 1075 - Estil kararı- Olay başlangıcı: Doktor, enjeksiyon esnasında damar ve arteri karıştırır-Sonuç: Kol kaybi.

63 COM (2020) 64 Final Raporu, 10.

64 Ibid.

65 Ibid.

66 COM (2020) 64 Final Raporu, 11. 


\section{Algoritmaların Şeffaf Olmayışının Olası Sonuçları}

Komisyon haklı olarak yapay zekânın - ve zararın ortaya çıkması halinde onun açıklanamayan ve aydınlatılamayan hatalı davranışının - önemli özelliklerinden birisinin, işleyişinin esasını oluşturan algoritmaların sıkı bir şekilde korunan ticarî sır olduğu gerçeğine dayandığını vurgulamaktadır ${ }^{67}$. Komisyon burada "şeffaf olmamadan" yani opaklıktan, kullanılan algoritmaların açık olmayışından söz etmektedir. Bu terminolojinin merkezinde, genellikle "yapay zekânın kara kutusu (BlackBox-KI)" bulunduğuna ilişkin tespit yer alır ${ }^{68}$. Bu bulgu yani yapay zekânın kara kutusu, bir zararın ortaya çıkması durumunda zarar görenin - sorumluluk hukuku anlamında kullanılan ve işlenen veri miktarlarından mesul belirli bir üreticiye veya işleyene ilişkin - nedenselliği gerçekten kanıtlama şansının olmamasına neredeyse kaçınılmaz olarak yol açar.

Dolayısıyla Komisyon’a göre: “Avrupa Birliği’nin ürün güvenliği düzenlemelerinde, algoritmaya dayanan sistemlerin şeffaf olmayışından kaynaklanan risklerin artışı açıkça ele alınmamaktadır. Bu sebeple, algoritmaların şeffaflı̆̆ının yanı sıra sağlamlığı, hesap verilebilirliği, gerektiği taktirde insan gözetimine olan gereklilik test edilmelidir. Ayrıca sonradan uygulama mekanizması ve bu teknolojilerin kullanımında güven tesis etmek için özellikle önemli olan sarih sonuçlar incelenmelidir. Bir kaza durumunda algoritmaların geliştiricilerini, veri kümelerinin tasarım parametrelerini ve meta verilerini açıklamakla yükümlü tutmak, bu zorluğun üstesinden gelmenin bir yolu olabilir" 69 .

Burada arka plânda Komisyon'un yapay zekânın "karmaşıklığına” dayandırılan bilgisi yer alır. Ancak bu bilgi Komisyon'un “yukarıda ele alınan karmaşıklığa ek olarak, bazı yapay zekâ sistemlerinde bulunan kara kutu etkisi nedeniyle, otonom yapay zekâ uygulamalarının yol açtığı zararların tazmin edilmesi zorlaşabilir"70 açıklaması ile daha da artmaktadır.

\section{Ispat Sorunları}

Sorumluluk hukukunun özünde var olan tüm bu güçlükler dikkate alındığında ${ }^{71}$, ispat sorunlarının ${ }^{72}$ üstesinden gelinmesi için yapay zekâ, nesnelerin interneti ve robotiğin bilhassa iki özelliği bulunmaktadır. Sorumluluk hukukunun dilsel kullanımına göre zarar görenin meselesi olan ispat yükü sorunlarına yönelindiğinde, ki bu gereklidir, söz konusu özellikler Komisyon’un yapay zekâyı tanımlaması temelinde göze çarpar ${ }^{73}$. Bununla birlikte 85/374 sayılı Üreticinin Sorumluluğuna

67 COM (2020) 64 Final Raporu, 11.

68 Ibid. - "Kara Kutu Etkisi”; Käde/von Maltzan, CR 2020, 66 ff. - Şeffaflık talebi; bu konuda ayrıca bkz. Zech, in: Lohsse/ Schulze/Staudenmayer (Fn. 13), 187, $192 \mathrm{f}$.

69 COM (2020) 64 Final Raporu, 11.

70 COM (2020) 64 Final Raporu, 18.

71 Bu konuda bkz. Rott, Gutachten (Fn. 4), 37 ff.

72 Avrupa Adalet Divanı’nın ispat yüküyle ilgili ürün sorumluluğu hukukuna dair kararı için bkz. EuGH v. 21.06.2017, Rs. C-621/15 - Sanofi Pasteur kararı, ECLI:EU:C:2017:484, NJW 2017, 2739; EuGH v. 20.02.2014, Rs. C-313/13 - Novo Nordisk Pharma kararı, ECLI:EU:C:2014:166, NJW 2015, 927; ayrıca bkz. Rott, Gutachten (Fn. 4), 26 f.

73 İspat yükünün değişmesi için ayrıca bkz. de Meuss, EuCML 2019, 149, 152 f., aksi yönde bkz. Seehafer/Kohler, EuZW 2020, 213 (216). 
İlişkin Avrupa Konseyi Direktifi'nin nedensellik meselelerini, ulusal hukuklara devrettiği dikkate alınmalıdır. Bu açıdan Komisyon'un şu iki ifadesi yol göstermektedir: "Yapay zekânın karmaşıklığı hem tedarik zincirinde yer alan ekonomik aktörlerin çeşitliliğinde hem de birlikte yeni teknolojik ekosistemler oluşturan bileşenlerin, parçaların, yazılımların, sistemlerin veya hizmetlerin çok sayıda olmasında kendini göstermektedir. Ayrıca, bu teknolojilerin piyasaya sürülmesinden sonra güncellemeler ve iyileştirmeler için açıklık vardır”74.

\section{Karmaşıklık}

BGB Art. 249 anlamında uygun nedenselliğin hukuk figürüne bağlı olan tüm mülahazaları unutmak için az önce açıklanan "şeffaf olmama” kavramına özel olarak bir kez daha değinmeden, "tedarik zinciri”nin "karmaşıklı̆̆g”na, bileşenlerin, parçaların, yazılımların, sistemlerin ve hizmetlerin ${ }^{75}$ "çeşitliliğine", - özellikle - de yapay zekânın piyasaya sürülmesinden sonra otonom güncelleme/ iyileştirmelerine işaret etmek yeterlidir. Yapay zekânın, otonom davranışının sonucu olarak bir zarara yol açan hatalı davranışı söz konusu olduğunda, zararın tazminin - yapay zekâya özgü - hukukî dayanağı çoklu nedensellik olgusu ${ }^{76}$ ya da BGB Art. 830 f. 1 c.2'den türetilen alternatif nedensellik ${ }^{77}$ ile açıklanabilir. Bu kısmen makul; ama pratik olarak da kullanışlı sebep olunan nedensellik modelini tanımlamak için gereklidir. Zech’e göre bir yapay zekâ ve işlevlerinin analizi, en iyi ihtimalle korelasyonlar hakkındaki bilgileri ortaya çıkarır ${ }^{78}$. Ancak bu analiz tek nedensellik olarak beliren illiyet zincirinin kesin çizgilerini oluşan zarara kadar aydınlatmaz. Son olarak, Zech’in bu temel düşüncesi dikkate alınmalıdır.

\section{Yanıt}

Bundan sonuçlar çıkarılırsa şu hükümden kaçınılması pek mümkün olmayacaktır: Kanun koyucu isterse illiyeti ispat araçları ile - ne ilk görünüşte ne de emarelerle ispat şeklinde - zarar görenin ispat zorluğunu yeterince güvenilir bir biçimde giderebilir. Komisyon bir yapay zekânın "birçok farklı bağlı cihaz ve hizmetin etkileşime girdiği karmaşık nesnelerin interneti ortamlarına entegre edildiği”" özel sorununu ele alırken bu bulguyu tam olarak dikkate alır ${ }^{79}$.

Zira Komisyon’a göre şu gerçekler dikkate alınmalıdır: "Karmaşık bir ekosistemdeki farklı dijital bileşenlerin kombinasyonu ve katılımcı aktörlerin çeşitliliği, hangi durumda potansiyel bir zarara yol açıldığını ve bu zarardan kimin sorumlu olduğunu değerlendirmeyi zorlaştırabilir. Bu teknolojilerin karmaşıklığı sebebiyle, sorumlu kişiyi tespit etmek ve başarılı bir talep için ulusal hukukun gerektirdiği

74 COM (2020) 64 Final Raporu, 2 (Orijinal metindeki kalın yazı tipi ile yazılmış kısım).

75 Ayrica bkz. Rott, Gutachten (Fn. 4), 39 - Birden fazla ürünün hatalı olması.

76 Bu konuda bkz. Zech, ZfPW 2019, 198 (207).

77 Zech, ZfPW 2019, 198 (208).

78 Zech, içerisinde: Lohsse, Schulze ve Staudenmayer (Fn 13), 185, 193.

79 COM (2020) 64 Final Raporu, 17. 
tüm koşulları kanıtlamak mağdur için çok zor olabilir. Delil sunmanın maliyeti ekonomik olarak katlanılamaz olabilir ve mağdurun tazminat talep etmesini engelleyebilir" ${ }^{\prime 0}$.

Komisyon'un sorumluluk hukuku bakımından yanıtlanması gereken ispat sorusuna nasıl bir cevabın verilebileceğine ilişkin sıkıntısı, bu cümlelerde ortaya çıkmaktadır. Bu sıkıntı, Komisyon’un tavsiyesi okunduğunda, daha iyi anlaşılır. Şöyle ki, Komisyon pratikte "yapay zekâ uygulamalarının çalışmasından kaynaklanan” zararların giderilmesi söz konusu olduğunda, "karmaşıklığın sonuçlarını" uygun ispat kurallarıyla azaltmanın nasıl mümkün olabileceğine dair üye devletlerin "görüşlerini" almak istemektedir" ${ }^{81}$.

\section{Siber Güvenlik ve Yapay Zekânın Saldırılara Karşı Açık Olması}

Ancak bir yapay zekânın, nesnelerin internetinin veya robotiğin karmaşıklığından ortaya çıkan hukukî sorunlar hali hazırda Avrupa kanun koyucusunun yeni sorumluluk düzenlemelerine dair üstesinden gelmesi gereken son mesele değildir. Bilakis, talep edilecek siber güvenlik ile ilgili yapay zekânın "bağlanabilirlik ve açıklığından” kaynaklanan özellikle zor bir soru ortaya çıkar. Burada üreticinin, bir bilgi teknolojisini piyasaya sürmeden önce yükümlü olduğu güvenlik gereklerinden; - hackerlar tarafından bulunan ve kullanılan - "zayıf bir noktanın” yapay zekânın işletilmesinden sonra ortaya çıkması halinde cevaplandırılması gereken güvenlik problemlerinden; kullanıcının, emniyetine ilişkin güncellemeleri kanunen veya sözleşme gereği yapmakla yükümlü olup olmadığ1 ve yükümlüyse de bunun kapsamının ne olduğuna kadar bir dizi soru bulunur ${ }^{82}$.

Henüz tamamen çözülememiş bu soru manzumesi, yapay zekânın hatalı davranışı nedeniyle somut zarar görenin nihayetinde zarara katlanacağı endişesini beraberinde getirir ${ }^{83}$. Bununla birlikte, Alman Federal Mahkemesi’nin kredi kartlarının kötüye kullanılması halinde bankanın sorumluluk hukuku alanında yerine getirmesi gereken güvenlik gereklerini çok yüksek tuttuğu unutulmamalıdır. Mahkeme, bilindiği üzere ilk görünüş delilinin kullanıcının aleyhine uygulanabilmesi için ödeme hizmeti sağlayıcısının kanıt sunmasını talep etmektedir. Bu kanıtla "güncel kararlara dayanarak uygulanan güvenlik yönteminin, somut olayda genel pratik aşılmazlığı ile bunun usulüne uygun kullanımı ve hatasız çalıştığı” ispatlanmalıdır ${ }^{84}$.

-İlgili risk ve zarar potansiyelinden bağımsız olarak - bir yapay zekânın (güvenli bir şekilde) çalışması için de bu gereklerin talep edilip edilemeyeceği şüphelidir. Fakat Alman Federal Mahkemesi’nin bu kararına yapılan atıf, yapay zekânın üretici/işletenin sağlaması gereken siber güvenlik açısından doğası gereği saldırılara açık olmasının, zarar görenin aleyhine ortaya çıkmasını engellemek için en azından hangi yönde düşünülmesi gerektiğine dair bir işaret olarak hizmet edebilir.

80 Ibid.

81 COM (2020) 64 Final Raporu, 17.

82 Ayrıca bkz. yeni Mal Satış Direktifi (AB) 2019/771'in (m 7) (4).

83 COM (2020) 64 Final Raporu, 18.

84 BGH NJW 2016, 2024 - 1. Düstur. 


\section{Yapay Zekâ Iş̧leteninin Zorunlu Olarak Sigortalanması Düşüncesi}

Özellikle bir motorlu araç işleteninin, aracı kullanırken üçüncü kişilere verdiği zararın giderilmesi için kanunen zorunlu sigorta yaptırması gerektiği göz önüne alındığında, bu düşünce yapay zekâ operatörü için de verimli hale getirmek mümkündür ${ }^{85}$. Bu hukuk politikası yaklaşımı hakkında kesinlikle tartışılması gereken çok şey olacaktır. Ayrıca riske ve zarara daha az eğilimli yapay zekâlar için illiyetin kanıtlanması alanında zarar gören lehine ispat yükününün tersine çevrilmesiyle ve ağırlaştırılmış sorumluluk ile yetinilip yetinilmeyeceğinin de düşünülmesi gerekir. Bununla birlikte, bu kuramsal bakış açısı, ikna edici özellikte değildir. Çünkü bir yapay zekânın tehlike derecesine göre sınıflandırılması amaca uygun olmaz. İster görkemli bir SUV ister göz bebeği gibi bakılan ve sadece yavaş sürülen klâsik bir araba olsun bir araç, zorunlu malî sorumluluk sigortası kapsamında her zaman bir araçtır.

\section{E. Sonuç}

"Yapay Zekâ, Nesnelerin İnterneti ve Robotiğin Güvenlik ve Sorumluluk Bakımından Etkileri" konulu yayınıyla Komisyon, Avrupa hukuku düzeyinde hangi yolun izlenmesi gerektiği hususunda çok yönlü tartışmalara yol açmak için suya bir taş atmıştır. Böylelikle, Komisyon'un haklı olarak ifadelerinin merkezine yerleştirdiği yapay zekâ, nesnelerin interneti ve robotiğin önemli özellikleri, ulusal (kusura bağl1) sorumluluk hukuku için ve 85/374 sayılı Üreticinin Sorumluluğuna İlişkin Avrupa Konseyi Direktifínde öngörülen ağırlaştırılmış sorumluluğun yenilenmesi gerekliliği için büyük bir patlayıcı güce sahiptir ${ }^{86}$.

Burada yapay zekâ, nesnelerin interneti ve robotiğin engel olarak tanımlanan ancak karakteristik özelliği olan kavramları odak noktayı oluşturmaktadır. Bunlar otonom olma, karmaşıklık, verilere bağımlılık, şeffaf olmama ve siber suçların oluşturduğu tehditlere karşı ele alınması - ancak ilk olarak oluşturulması - gereken güvenlik kurallarıdır. Söz konusu kavramlar, özellikle bu sistemin diğer karakteristik özelliklerinden yani açılık ve bağlanabilirlikten kaynaklanabilir. Bu özelliklerin sadece tüketicinin değil - zarar görenin lehine de adil bir sorumluluk düzenlemesi anlamında hukuk politikası bakımından ve nihayetinde de kanunen ele alınması, Avrupa hukuk sisteminden erken bir cevap verilmesini gerektirir.

85 Borges, in: Lohsse/Schulze/Staudenmayer (Fn. 13), 145, 148 ff.; aynı şekilde bkz. NJW 2018, 977 (982); Graf von Westphalen, ZIP 2019, 889 ff.

86 Daha fazla yol gösterici hukukî bilgi ve talep için bkz. Ebers, VuR 2020, 121 (122); buna karşın oldukça ihtiyatlı değerlendirme için bkz. Seehafer/Kohler, EuZW 2020, 213 (218) - Sadece bir ürün gözlemleme yükümlülügünün yerine getirilmesi ile ilgili değişiklik. 